STATE OF ALASSKA.

PROPERTY OF

LIBRARY

STATE OF ALASKA DIVISION OF. MINES ANO MINERALS.

\title{
MINES AND PETROLEUH BULLETIN
}
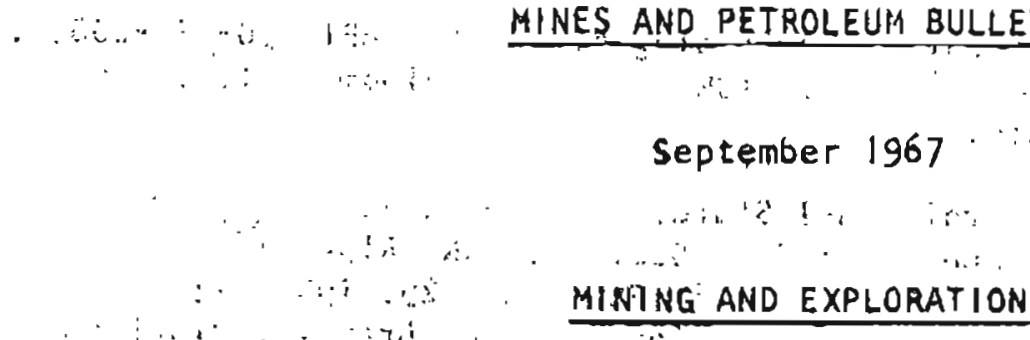

Northwest - Kennecott cblpper Corpi has plugged the bottom of its flooded shaft at Bornite with cement. The shaft flooded last fall in spite of carefuldrlling ahead and grouting" whieh" the ilasit round was blasted: at "target depth" of about 1070 feet. Four thou'sand sacks of cement (eighi carloads) were flown. to the property and used in the pour'. No eggregate was used. The cement was poured under: water, arfy it fillied the shaft to a depth of about 23 feet above the bottom. After a 30 day cure, pumping will be comenced, and resumption. of underground excavation and exploration will follow.

\section{OIL AND GAS NEWS}

Ten applications for drilling permits were approved by the Division's Petroleum Branch as follows: : Q $91:$ :

Remnizoil Company \#1 Starichkof Unit,. API $\$ 50-231-20001,760$ fNL and W 18801 FEL, Sec. 22, T35, R1.5W, S.M: This exploratory location.

i:psioffshore and about 20 miles northwest of Homer.

in i in

$\therefore$ is.

$\therefore: x$ :

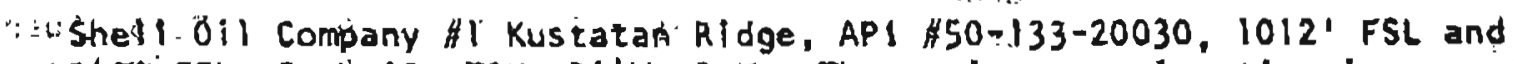

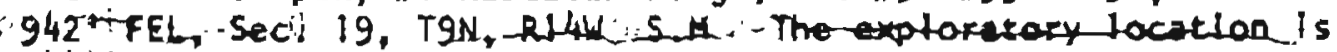
ohishore and about twelve mlles wes $x$ of the Middle Ground Shoal Field,

Union Oil Company of Californila West Trading Bay State. API 450-13320031. 1200' FNL E' 800' FWL, SeC. 4, T9N, RI3W, S.M. This: developgene well is in the Trading Bay Fleld Area.

Shelirio il Company :HA-42-14 MIddle Ground Shoal, API \#50-133-20029.

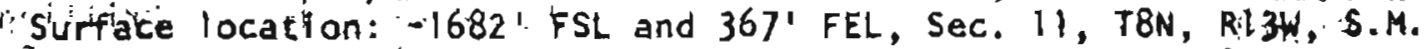

'ausottom hole location: $-2500^{\circ} \mathrm{FNL}$ and $820^{\circ} \mathrm{FEL}, \mathrm{Sec} .14, \mathrm{~T} 8 \mathrm{~N}, \mathrm{R} / 3 \mathrm{~W}$,

S.M." "Thls development location is in the Middle Ground: Stroet fleld...

: " Thls development ilocation is in the kiddle Ground:

- Pan American Petroleum Corporation \#10 Granite Point State 18742, .

APf H50-133-20032. Surface location: 1948' FSL and 1979'. FWL' Ser, 31, TPlifi' RIIW, S.M. Bottom hole fadation: 660' FNL and 660' : FWL;

Sece. TION, RIIW, S.M. This development location is in the Granite Pódintífield.

Tenrieco 011 Company \#1 State. 36465, API 50-133-20033 I' FSL and 2500! Fill, Sec. 34; T7N, RI4W, S.M. This offshore exploratory location Is 15 .. miles northwest of Kenal. 
Atlantic Richfield Company 1 Middle RIver State Unit, API \#50-13320034. 660' FNL and 660' FEL, Sec. 20, TION, RI3W, S.11. This offshore exploratory location is three miles northwest of the Trading bay field.

Union Oll Company of Call fornia \#A-7 Trading Bay State, API \$50-133-20036. $1615^{\prime}$ FSL and 56/' FEL,"SeC. 4, T9N, RI3W." This development location is in the Trading Bay field.

Union Oil Company of California \#G-1 State, API \$50-133-20037. Surface location: $1886^{\prime} \mathrm{FSL}$ and $1386^{\prime} \mathrm{FEL}$, Sec. 29, T9N, RI3W, S.M. Bottom hole location: $1450^{\prime} \mathrm{FL}$ and $1386^{\circ} \mathrm{FEL}$, Sec. 29, T9N, RI3W S.M. This is the first development location from the Grayling Platform in the Trading Bay Unit, 2 1/2 miles south of the Trading Bay Field.

Unión oil company of Callfornia \$G-2 State, AP! \#50-133-20038. Sura-... face location:" 1829" FSL E 1480 ' FEL, Sec. 29, T9N, RI3H, S.M. Bottom hole location: - 570' FSL and 2020' FEL, Sec. 29, T9N, RI3W; 5.M. This is the second development location from the Grayling Platform, and and is an offset to the discovery well of the McArthur River fileld.

Drilling Activity

Operator

Atlantic 'Richfield Co. Atlantic Richfleld Co. At lantic Richfleld Co. Humble oil E Refining Co. Marathon 011 Company Mobil Oil Corp. Mobil Oil Corp. Hobil oi 'illorp. Mobil 011 Corp. Pan Anerican Petroleum Coŕp. Pan American Petroleum Corp. Pan American Petroleum Corp:" Pan American'Petroleum Corp: Pan American Petroleum Corp. Pan American Petroleum Corp. Pan American Petroleun Corp.: Pan American Petroleum Corp. Pan Amerlcari Petroleum Corp: Pan American Petroleum Corp. Pan American Petroleum Corp. Pan American Petróleum Corp: Pan American Petroleum Corp. Pan Anerican Petroleum Corp: Pan American Petróledm Corp. Pennzoil Co. Placid Dil Company Shell oil co. Shell oil Co.' is ...: $\because$ : Shell oil Co. Shell oil Company
Wéli Names and Numbers

Type

Milddle River State Uhit Prudhoe Bay HI

Trading Bay State $\$ 2$ Tyonek Reserve "B" Bejver Creek \#2 Granite Pollnt State \#11-13

Granite Polnt State $\# 13-13$

Granite Point State \#3t-14 $\because$ D

Tower H2: : . a... $\because \cdots$

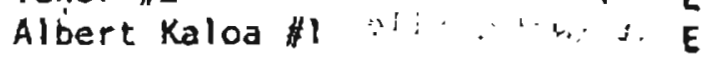
Foreland State Unit \#1 Granite Point State $1758.744 . \cdots$ Granite Polnt State $187420 \%$ Granite Point State 18742 . 46 D Granite Point State 18742 . 7 Granite Point State:18742 48 D. Granite Point State 18742 : \$9:11: 0 Granite Point State 18742 \#10.5. 0 MGS State 17595 \#10 MGS State 17595 \#11 North MGS State 18.745 \#2 Redoubt Shoal State :H: South MGS Unit \#2 $\quad$, : : i: South MGS Unit \#3 Starichkof Unit \#l State 17580 \#1

Kustatan Ridge \#1:: MGS $\# A-33-1$

MGS $\# A-42-14$ MGS $\# A-44-11$

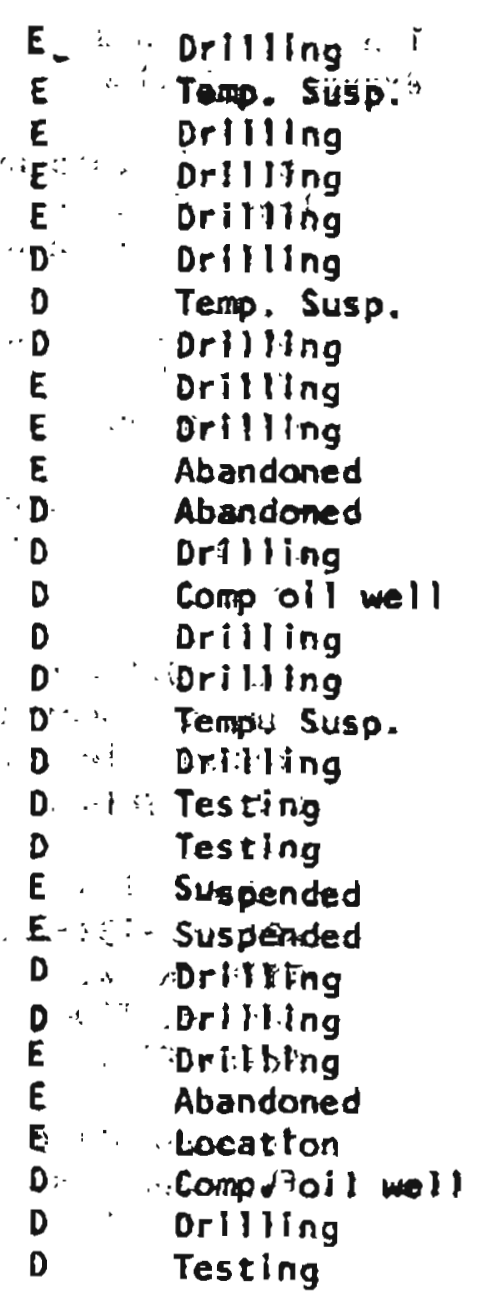


Standard Oll co. of Calif. Superior oll Company Tenneco oil Company Union'opl co. of Calif. Unian. Q 1 , co, iof calif. Union oil co. of Callf. Union $011 \mathrm{Co}$. of Callf. Union 0il. Ca of Calif. unlon oij.co: of Calif.
Beluga River Unit $\$ 14=3$

Three Mile. Creek State \#1

State 36465 \#l

Kenal

Trading Bay State $\# A-3$

Trading Bay State $\$ A-7$

State $G-1 \quad(32-28)$

State GT2. (34-29)

West Trading Bay State HI $\begin{array}{ll}\text { D } & \text { Testing } \\ \text { E } & \text { Drilling } \\ \text { E } & \text { Drilling } \\ \text { D } & \text { Location } \\ \text { D } & \text { Suspended } \\ \text { D } & \text { Location } \\ \text { D } & \text { Location } \\ \text { D } & \text { Location } \\ \text { E } & \text { Orflled \& Abandoned }\end{array}$

* "E" indicates an exploratory well, and "D" a development well.

Production ion

\begin{tabular}{|c|c|c|c|c|c|}
\hline Field & : & Zone & Prod. Wells & $011,8 \mathrm{~b} / \mathrm{s}$. & Gas, MCF \\
\hline Swanson & River field & Hemlock & 34 & $\begin{array}{c}1,090,528 \\
69,339,332\end{array}$ & $\begin{array}{c}1,096,773 \\
25,283,496\end{array}$ \\
\hline & & $\begin{array}{l}\text { Injection } \\
\text { Hemlock }\end{array}$ & 8. (ins) & $\therefore \because \therefore$ & $\begin{array}{c}3,611,951 \\
66,298,841\end{array}$ \\
\hline
\end{tabular}

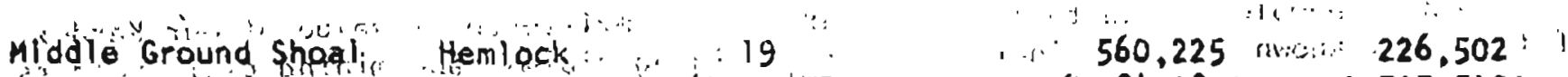

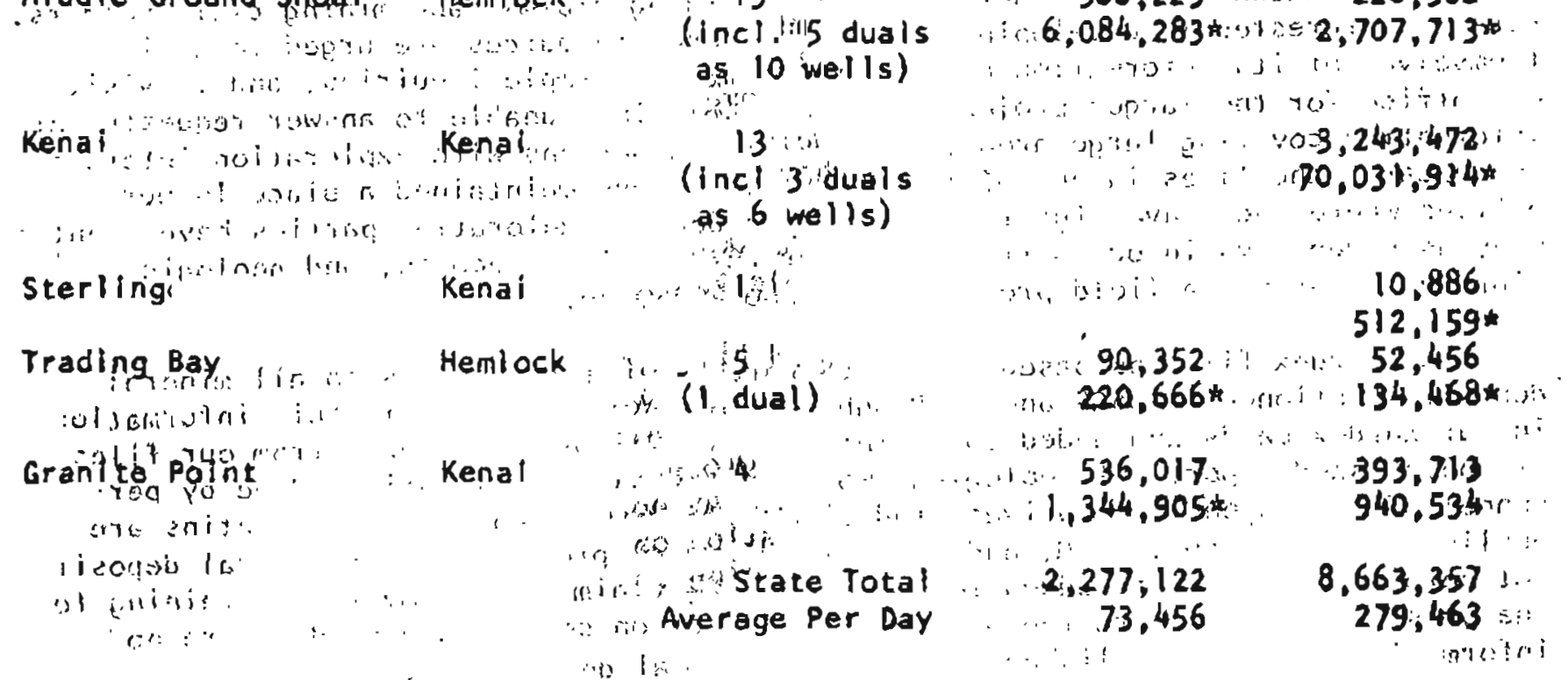

*Cumulative to August 1,1967

\section{DIVISION ACTIVITIES}

The Fairbanks flood has not changed our plans for theinove, but it. will now be delayed, of course. We are guessing at the moment that about the end of ocrober stould see us consolidated. in. the new quarters at. Collegeb..'. 


\section{NEW PUBLICATIONS}

The $u$. Geological Survey has: published a dictionary of Alaska place namies. It contains ! 1084 pages and nearly 44,000 entries. Each entry identifles and locates the feature named, lists different spellings of the name if such exist; and other names previously applied to the feature. History and origin of each náme are given when possible. The title is "Dictionary: of Alaska Place Names" by doh'ald H. Orth, and it is published as USGS Professionalipaper.567. It may be purchased. from the Superintendent of Documents, Government-Printing Office, Washington, D.C., 20402 , for \$8:50, or over the counter (not. by mail), from the Geological Survey Public: inquiries office, Skyline Building, Anchorage. Please do not order this publication from the Division of Mines and. Minerals:

The Proceedings. of the Third: Golduand Money Session, iwich was held in conjuction with the Pacific Northwest Metals and Minerals Conference at Port land last April is now available. Three papers have been added to those presented at the conference, and a verbatim transcript:of the.panel session is included. It is available for the price of $\$ 2.00$ from the Oregon Deparment of Geology and Mineral Industries, 1069 State Office Building. Portland, Oregon, 97201. Pléase do not order this publication from the Division of Mines and Minerals

\section{$\therefore \quad \therefore \quad$ OMEM CENTRAL RECOROING ANO MINERAL INVENTORY}

Mining people are:quite of ten unaware of the existence or value:?of iour Kardex file of all known Alaskan mineral deposits, :mining claims, and mining claim holders. Persons interested in developing Alaska!s mineral resources are urged to avail themselves of its information by mail for the more simple inquiries, and to vislt our affice for the larger projects. We are sometimes urable to answer requests for infiapration covering large areas, but. we welcome persons with exploration interests to research the flles in our office. We have always maintained a place in our offices where such investigative work can be done. Exploration parties have spent as many, as, iseven days in our office using our Kardex file, reports, and geologfea'l librariy, sta: lay out a field program for a whole season.

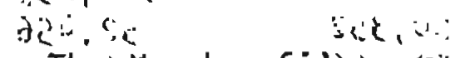

The Kardex fileiwasjbased on a USGS card file of references to all mineral deposits mentioned in USGS and USBM publications. We entered all this information.

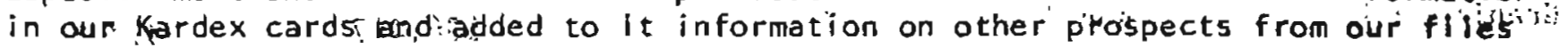
of unpublished reports. dfi.geological work and prospect examinations done by personnel of this agency and private individuals. As new reports and bulletins are publis ishedi byc the USES. USBM and DMEM, information on prospects or mineral deposits not before, mentioned are added to the file. Mining claim information pertalning to the prospects is added to the appropriate cards, or on separate cards where no information has been published regarding the mineral deposit, staked,

Each card shows:

(1) If claims have been staked on a particular prospect,

(2) if they have, by whom, names: of: the claims; and other information,

(3) if there is published information on the prospect,

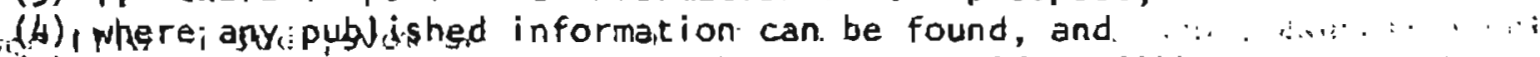

(5) quineralgaicalojaformation: on he prospect, if avarlable. in $\cdots, \ldots$ i. i v

One card usualiy exists for each prospect or group of claims. On the raw 
occasions where-nore than -one card exists, they are cross referenced to each other so that no information is missed. The file presently contains approximately 6000 cards.

The cards are filed according to tine USGS quadrangle (scale. ${ }^{\prime \prime}=4$ miles) within which the occurrences lie. There are 153 quads covering the State. The location is pinpointed as accurately as descriptionsion the claim location. certificate or published description allows. The pinpointing is done by means of coordinates in inches and tenths from the left and bottom edges of the quadrangle, map. A separate coordinate card file of all occurrences is maintained. As new information is recelved, the coordinate file is checked before a new card is made out to see whether a card lalready exists for the particular occurrence staked or reported. This insures that all information pertalining to one location or oceurrence is included on one.card or corss-referenced. When staking conflicts are evident, we usually notify both parties or a confidential basis in case they are not:aware of the; conflict. This helps avold - toút ticases and other problems.

The mining claim information is taken from duplicate copies of recorded location ceritlficates and assessment work affidavits wiich have been coming to us from all the recorders of the State and Former Territory since 1953. This information is added to the Kardex cards as already described, but. is also filed four other ways for it: convenlence in finding desiredriclaim information.: from the location certiflcate. the following information is typed on a triplicate form:

(i) name of owner

(2). name of claim,...: :

(3) mineral for which claim was probably staked, and

(4) USGS quadrangle within which the claim lies.

Assessment work informationis added to these forms each year from the affidavits coming in. The certificate or affidavit document is filed alphabetically by owner's name withingthe USGS quadrangle, where the claim is located. The three copies of the triplicate form are filed three ways:

(1) alphabetically by owner's name without regard to quadrangle, :

(2) alphabetically by claim name without regard to quadrangle, and

(3) alphabetically by mineral staked and by owner's name within, each. -mil neral category.

As already mentioned, another file is made up of the coordinates of the clalm locatlons and $\mathrm{filed}$ by quad and numerical order of the coordinates. Thus, reference to a clalm can be found in our files from several different directions, depending: on what information is available. Information on patented claims is also included.

The top lines of the Kardex card have spaces for the following information to be entered (either spelled out or in code) so that the main points of the occurrence can ibe ascertained by a glance as one riffles through the file:

(1) Recording precinct, mining district, coordinates, quad number,

(2) serial number (of prospect), metallic minerals, nonmetallic minerals,

(3) land status (open, staked, or patented), development, production,

(4) filed information, published information, date last visited,

(5) merit, and active or idle.

The two sides of the card expand on this information, add other information, and give all known references where further information can be obtained. Thus in a matter of mimutes we can find whether a particular prospect has been staked, exactiy where certain claims may lịe, what claims may lię within a certain area, who may be holding claims, mat publistud information may exist on certain prospects, what deposits of 
a particular mireral may lie in certain areas, etc.

Examples of questions that we can easily answer by mail are the following:

Are, there any: claims on Fish Creek in the Fortymile?

Where does Joe Doakes hold claims?

is the Neversweat prospect on Admi ralty Island open for staking?

What information is available on the Eagle antimony prospect?

What molybdenum prospects are located in the area of lliamna Lake?

if the recorder is doing his job properly, he places the address of the claim owner on the location certificate if it is not there already. We can then furnish this adoress: when someone wants to get in touch with the holder of certain claims.

Al) that is needed to make the system complete in one office is for a draftiman to plot the claims on quadrangle maps at a scale of $1^{\prime \prime}$ equals "inile for distribution. ...i Thjs! will hopable interested persons to see the locatlons easily,. tie the claims in :- wi.th the Kardex.information, and use the maps for field work. The claim maps can easily. be plotted with the information already on hand and the current information coming in. The maps should be revised at appropriate times to keep them curreitit, depending on the activity in the area. With our approaching consolldation at Fairbanks (College) a draftsman for this purpose and for drafting maps for, our geological and other reports is anticipated. In the relatively few areas where State land is involved, the claim maps can be sent to the Diyision of Lands for combining with other land status information, if desired. A few maps of the more congested areas near Fal rbanks. showing claims and land stetus have been published by the Division of Lands.

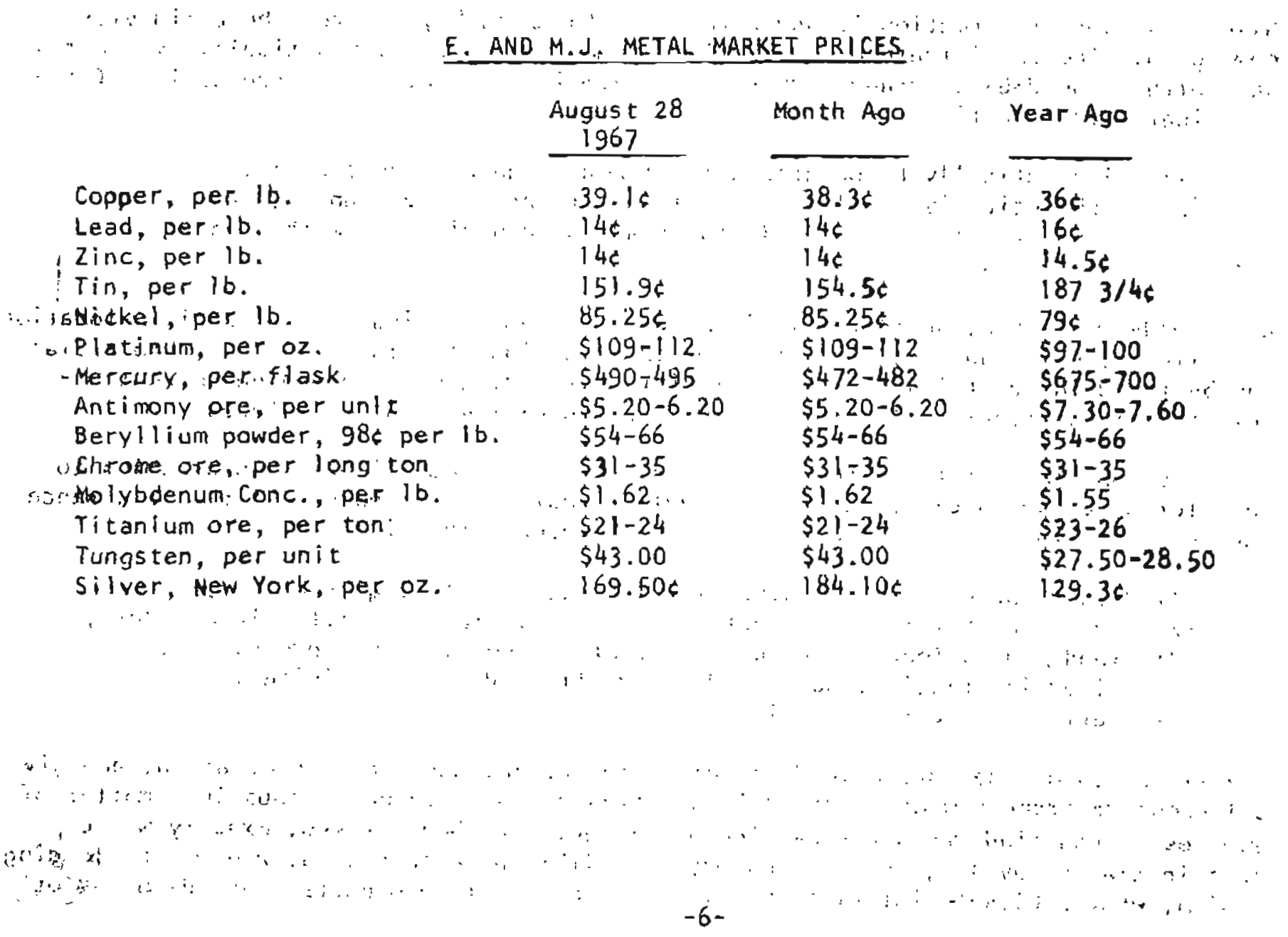

